\title{
КЛІНІКО-СТАТИСТИЧНЕ ДОСЛІДЖЕННЯ РІВНЯ АМПУТАЦІЇ КІНЦІВКИ У ПОРАНЕНИХ
}

\author{
Є. В. Цема ${ }^{1}$, І. П. Хоменко ${ }^{2}$ А. А. Беспаленко ${ }^{1,3}$, О. А. Бур'янов ${ }^{1}$, В. Г. Мішалов ${ }^{1}$, А. Ю. Кіх ${ }^{3}$ \\ ${ }^{1}$ Національний медичний університет імені О.О. Богомольця МОЗ України, \\ 2 Національний військово-медичний клінічний центр МО України, м. Київ, \\ ${ }^{3}$ Військово-медичний клінічний центр професійної патології особового складу Збройних Сил України, м. Ірпінь
}

\section{CLINICO-STATISTICAL INVESTIGATION OF THE EXTREMITY AMPUTATION LEVEL IN WOUNDED PERSONS}

\author{
E. V. Tsema1, I. P. Khomenko², A. A. Bespalenko ${ }^{1,3}$, O. A. Buryanov', V. G. Mishalov ${ }^{1}$, A. Yu. Kikh ${ }^{3}$ \\ ${ }^{1}$ Bogomolets National Medical University, \\ ${ }^{2}$ National Military-Medical Clinical Centre MD of Ukraine, Kyiv, \\ ${ }^{3}$ Military-Medical Clinical Centre of the Personnel Professional Pathology of Military Forces of Ukraine, Irpin
}

\begin{abstract}
Реферат
Узагальнені результати лікування 159 постраждалих, у яких виконано ампутацію кінцівок, у період 2014- 2016 рр. Вік постраждалих від 18,9 до 60,3 років, у середньому $(33,04 \pm 1,15)$ року, $158(99,4 \%)$ з них- чоловіки, 1 (0,6\%) жінка. Основною причиною втрати кінцівки були: мінно-вибухове поранення-у 74,8\% постраждалих, осколкове-у 9,4\%, кульове - у 6,9\%, холодова травмау 4,4\%. У 4,4\% постраждалих відзначені вибухова травма (заброньовані пошкодження), дорожно-транспортна пригода та обвал бетонних конструкцій. В структурі бойової хірургічної травми переважала ампутація нижньої кінцівки- у $67,5 \%$ спостережень, верхньої- у 32,5\% ( < 0,001). Частота ампутації сегментів верхньої кінцівки становила: плечового- 29,0\%, ліктьового- 40,3\%, кисті- 30,6\% ( $p=0,35)$; нижньої кінцівки: стегнового сегмента- 42,6\%, гомілкового- 41,1\%, стопи- 16,3\% ( $<<0,001)$. Особливості структури ампутації кінцівок слід мати на увазі при визначенні потреби у протезуванні постраждалих.

Ключові слова: бойова травма; ампутація кінцівки; структура.

Abstract

Results of treatment of 159 injured persons, in whom the extremities amputation was performed in 2014- 2016 yrs, were summarized. The injured persons were aged from 18.9 to $60.3 \mathrm{yrs}$ old, $(33.04 \pm 1.15) \mathrm{yrs}$ at average, $158(99.4 \%)$ of them- men, and $1(0.6 \%)-$ woman. The main cause of the extremity loss were: the mine-explosive wounding- in $74.8 \%$ of injured persons, a splinter one- in $9.4 \%$, the bullet - in $6.9 \%$, the cold trauma- in $4.4 \%$. In $4.4 \%$ of the injured persons the explosive trauma was noted (booked injuries), a road-transport accident and collapse of a concrete constructions. In the combat surgical trauma structure a lower extremity amputation have had dominated, occurring in $67.5 \%$ observations, and of the lower extremity- in $32.5 \%(p<0.001)$. The amputation rate of the upper extremity segments constitutes: of the brachial segment- $29.0 \%$, of the ulnar segment- $40.3 \%$, of hand- $30.6 \%(p=0.35)$; and of the lower extremity: of the femoral segment $-42.6 \%$, of the shin segment- $41.1 \%$, and of the foot segment- $16.3 \%(p<0.001)$. While determining the necessity in prosthesis in the injured persons the extremities amputation structure must be taken into account.

Keywords: combat trauma; amputation of extremity; structure.
\end{abstract}

В останні роки актуальною є проблема лікування постраждалих 3 приводу вогнепальних поранень внаслідок мінометних обстрілів та застосування реактивної артилерії. у значної частини постраждалих 3 вогнепальними пораненнями виявляють ушкодження верхніх і нижніх кінцівок, що безпосередньо (поранення магістральної судини, мінновибухове відчленування, вибухове розтрощення) чи внаслідок ускладнень спричиняють втрату сегмента кінцівки [1 - 5].

Тяжко пораненим надають багаторівневу медичну допомогу, що включає догоспітальний та госпітальний етапи. На догоспітальному етапі пораненим надають першу медичну та долікарську допомо- гу (базовий рівень) та першу лікарську допомогу (І рівень). Першу медичну допомогу надають на місці поранення в порядку само- та взаємодопомоги, після чого пораненого евакуюють санітарним транспортом до найближчого місця надання кваліфікованої медичної допомоги. Якщо неможливо здійснити евакуацію на етап кваліфікованої медичної допомоги протягом 1 год (принцип «золотої години»), пораненим надають першу лікарську допомогу в розгорнутих стабілізаційних пунктах, де працюють лікарі-фахівці з невідкладних станів. Долікарську допомогу надає середній медичний персонал під час евакуаційних заходів [4, 6 - 9]. Госпітальний етап надання медичної допомоги пораненим вклю- чає II, III, IV та V рівень. Кваліфіковану хірургічну допомогу (II рівень) надають у міських та районних лікарнях, в яких працюють групи підсилення з військових лікарів, а також у розгорнутих військових мобільних шпиталях. Зазначені лікувальні заклади діють в мінімально-допустимій близькості до лінії зіткнення, що сприяє реалізації принципу «золотої години» у 80\% поранених. На етап кваліфікованої медичної допомоги постраждалий потрапляє, як правило, протягом 60 хв після поранення.

Спеціалізовану хірургічну допомогу (III рівень) надають в одному 3 трьох прифронтових багатопрофільних лікувальних закладів: Військово-медичному клінічному центрі Північного регіону (Харків), 
Військовому госпіталі (Дніпро), Обласній клінічній лікарні імені I. I. Мечникова (Дніпро). Строки евакуації на III рівень надання медичної допомоги обмежені стабілізацією загального стану постраждалого. Евакуацію на цей рівень здійснюють 3 використанням автотранспорту (реанімобіль), залізничного (потяги «InterCity») та авіаційного (гелікоптери) транспорту.

IV рівень медичної допомоги передбачає надання пораненим вичерпного обсягу спеціалізованої медичної допомоги $з$ використанням високотехнологічного устаткування. На цьому рівні медичну допомогу надають у Національному (Київ) або регіональних військово-медичних клінічних центрах (Вінниця, Одеса, Львів), в які постраждалих евакуюють авіатранспортом.

$\mathrm{V}$ рівень медичної допомоги передбачає проведення реабілітаційних заходів (в тому числі протезування втраченого сегмента кінцівки) у відповідних військових та цивільних лікувально-профілактичних закладах.

Важливе місце у збереженні травмованого сегмента кінцівки відіграє наявність та доступність на етапі спеціалізованої хірургічної допомоги сучасного високотехнологічно- го обладнання (артроскопія, системи для VAC-терапіі, сучасне протезувально-ортопедичне забезпечення) $[4,10-12]$.

\section{МАТЕРІАЛИ I МЕТОДИ ДОСЛІДЖЕННЯ}

Проаналізовані результати лікування 159 постраждалих, яким виконано ампутацію кінцівок в період 3 2014 по 2016 р.

Усі постраждалі належали до військових формувань, безпосередньо брали участь у бойових діях, тобто, мали статус комбатантів. Поранених та постраждалих, які не мали статусу комбатантів (цивільне населення, журналісти, працівники комунальних служб військово-цивільних адміністрацій, рятувальники державної служби надзвичайних ситуацій), проте, отримали травму в зоні бойових дій, що спричинило ампутацію кінцівки, у дослідження не включали, лікували переважно у закладах системи охорони здоров'я України.

Вік постраждалих на момент поранення у середньому $(33,04 \pm 1,15)$ року, наймолодшому було 18,9 року, найстаршому - 60,3 року. Ампутація кінцівок здійснена у 158 (99,4\%) чоловіків та в $1(0,6 \%)$ жінки.

Основним видом ушкодження, що зумовив втрату сегмента кінцівки,

Таблиця 1. Структура ампутованих кінцівок у досліджуваних хворих

\begin{tabular}{|ccccccc|}
\hline \multirow{2}{*}{$\begin{array}{c}\text { Ампутована } \\
\text { кінцівка }\end{array}$} & \multicolumn{3}{c}{ Ампутована кінцівка } & \multicolumn{2}{c|}{ Разом } \\
\cline { 2 - 6 } & \multicolumn{3}{c}{ ліва } & \multicolumn{2}{c}{ права } & \\
\hline & абс. & $\%$ & абс. & $\%$ & абс. & $\%$ \\
\hline Верхня & 31 & 16,2 & 31 & 16,2 & 62 & 32,5 \\
\hline Нижня & 63 & 33,0 & 66 & 34,6 & 129 & 67,5 \\
\hline Загалом ... & 94 & 49,2 & 97 & 50,8 & 191 & 100,0 \\
\hline
\end{tabular}

Таблиця 2. Характеристика рівня ампутації верхньої кінцівки

\begin{tabular}{|lccc|}
\hline \multicolumn{1}{|c}{ Операція } & $\begin{array}{l}\text { Кількість } \\
\text { операцій }\end{array}$ & $\begin{array}{c}\text { \% від ампутації } \\
\text { верхньої } \\
\text { кінцівки }\end{array}$ & $\begin{array}{c}\text { \% від усіх } \\
\text { операцій } \\
\text { ампутації }\end{array}$ \\
\hline $\begin{array}{l}\text { Екзартикуляція на рівні } \\
\text { плечового суглоба }\end{array}$ & 2 & 3,2 & 1,3 \\
\hline Ампутація на рівні & 2 & 3,2 & 1,3 \\
\hline верхньої третини плеча & 8 & 12,9 & 5,0 \\
\hline середньої третини плеча & 6 & 9,7 & 3,8 \\
\hline нижньої третини плеча & 6 & 9,7 & 3,8 \\
\hline верхньої третини передпліччя & 4 & 6,5 & 2,5 \\
\hline середньої третини передпліччя & 15 & 24,2 & 9,4 \\
\hline нижньої третини передпліччя & 2 & 3,2 & 1,3 \\
\hline суглобів кисті & 4 & 6,5 & 2,5 \\
\hline міжзап'ясткових суглобів & 13 & 21,0 & 8,2 \\
\hline Екзартикуляція фаланг пальців & 62 & 100,0 & 39,0 \\
\hline Разом ... & & & \\
\hline
\end{tabular}

були мінно-вибухові пораненняу 119 (74,8\%) постраждалих, осколкові поранення- у 15 (9,4\%), кульові вогнепальні поранення - в 11 (6,9\%), холодова травма - у 7 (4,4\%). У 3 $(1,9 \%)$ постраждалих було заброньоване ушкодження (вибухова травма під час перебування у бронетехніці), у 2 (1,3\%) - дорожно-транспортна пригода, у 2 (1,3\%) - обвал бетонних конструкцій 3 формуванням синдрому тривалого стискання кінцівки. 3119 травмованих з мінно-вибуховими пораненнями у 69 (58,0\%) обставинами травми був артилерійський обстріл, у 18 (15,1\%)- підрив на мінній розтяжці, у 14 (11,8\%)- детонування вибухового пристрою, у $4(3,4 \%)$ - вибух гранати в руці, в 1 (0,8\%) - танковий обстріл. У 13 (10,9\%) постраждалих причина мінно-вибухового поранення не встановлена через відсутність або неналежне оформлення медичної документації.

Критерії включення пацієнтів у дослідження.

1. Місце виникнення ушкодження: зона бойового конфлікту.

2. Період виникнення поранення: 2014-2016 pp.

3. Статус пораненого: комбатант.

4. Характер ушкодження: будь-яке ушкодження, що спричинило втрату сегмента кінцівки.

5. Характер оперативного втручання: ампутація або екзартикуляція сегмента кінцівки, в тому числі операції в обсязі первинної хірургічної обробки ран кінцівки 3 приводу іiі травматичного відчленування.

6. Місце надання кваліфікованої та спеціалізованої хірургічної допомоги: відомчі лікувальні заклади Міністерства оборони України (обов'язково); цивільні лікувальні заклади та лікувальні заклади інших держав.

7. Тривалість спостереження: від виникнення травми до початку реабілітації або смерті.

Критерії виключення з дослідження.

1. Місце виникнення ушкодження: поза зоною проведення бойових дій.

2. Статус пораненого: цивільне населення, журналіст, працівник комунальних служб військово-цивільних адміністрацій, рятувальник державної служби надзвичайних ситуацій. 
3. Характер ушкодження: будьяке ушкодження, що не спричинило втрату сегмента кінцівки.

4. Місце надання кваліфікованої та спеціалізованої хірургічної допомоги: відомчі лікувальні заклади Міністерства внутрішніх справ України, Служби безпеки України, Державної прикордонної служби України.

5. Тривалість спостереження: відсутність даних до початку реабілітації або смерті пораненого.

\section{РЕЗУЛЬТАТИ}

\section{ТА ÏХ ОБГОВОРЕННЯ}

Втратили сегмент верхніх кінцівок 54 (34,0\%), нижніх кінцівок - 113 (71,1\%) постраждалих. Тобто, виконували переважно ампутацію нижньої кінцівки $\left(\chi^{2}=43,9, \mathrm{p}<0,001\right)$, що пов'язане з тим, що ударна хвиля при мінно-вибуховому пораненні поширюється з низу вгору, і за положення людини під час вибуху стоячи, основних ушкоджень зазнають саме нижні кінцівки. У 91 (59,1\%) постраждалого виконана ампутація лівої кінцівки, у 92 (61,0\%)- правої $\left(\chi^{2}\right.$ $=0,01, \mathrm{p}=0,91)$.

В структурі оперативних втручань (табл. 1) переважали операції на нижніх кінцівках - у 129 (67,5\%) постраждалих ( $\left.\chi^{2}=47,0 ; \mathrm{p}<0,001\right)$, достовірної різниці між частотою ампутації правих та лівих кінцівок не було $\left(\chi^{2}=0,09, \mathrm{p}>0,76\right)$.

Структура ампутації верхньої кінцівки залежно від рівня ампутації наведена у табл. 2. У 28 (45,2\%) постраждалих ампутація верхніх кінцівок здійснена на рівні дистальних відділів, пальців та нижньої третини передпліччя. Ампутація сегмента кінцівки виконана у 41 (66,1\%) постраждалого, екзартикуляція на рівні суглоба - у 21 (33,9\%). На проксимальному сегменті верхньої кінцівки операція виконана у 18 (29,0\%) постраждалих, на передпліччі - у 25 (40,3\%), дистальному сегменті - у 19 (30,6\%). Достовірної різниці частоти операцій на різних сегментах верхньої кінцівки не було $\left(\chi^{2}=2,1, \mathrm{p}=\right.$ 0,35).

Аналіз операцій ампутації нижньої кінцівки залежно від рівня втрати сегмента наведений у табл. 3. У 87 (67,4\%) постраждалих ампутація нижніх кінцівок здійснена на рівні середньої третини стегна та гоміл-

Таблиця 3. Характеристика рівня ампутації нижньої кінцівки

\begin{tabular}{|lccc|}
\hline \multicolumn{1}{|c}{ Операція } & $\begin{array}{c}\text { кількість } \\
\text { операцій }\end{array}$ & $\begin{array}{c}\text { \% від ампутації } \\
\text { нижньої } \\
\text { кінцівки }\end{array}$ & $\begin{array}{c}\text { \% від усіх } \\
\text { операцій } \\
\text { ампутації }\end{array}$ \\
\hline $\begin{array}{l}\text { Екзартикуляція на рівні } \\
\text { кульшового суглоба }\end{array}$ & 5 & 3,9 & 3,1 \\
\hline Ампутація на рівні & 4 & 3,1 & 2,5 \\
\hline верхньої третини стегна & 34 & 26,4 & 21,4 \\
\hline середньої третини стегна & 12 & 9,3 & 7,5 \\
\hline нижньої третини стегна & 16 & 12,4 & 10,1 \\
\hline верхньої третини гомілки & 17 & 13,2 & 10,7 \\
\hline середньої третини гомілки & 20 & 15,5 & 12,6 \\
\hline нижньої третини гомілки & 4 & 3,1 & 2,5 \\
\hline $\begin{array}{l}\text { надп'ятково-гомілкового } \\
\text { суглоба }\end{array}$ & 5 & 3,9 & 3,1 \\
\hline стопи за Шопаром & 4 & 3,1 & 1,3 \\
\hline стопи за Лісфранком & 2 & 1,6 & 3,8 \\
\hline $\begin{array}{l}\text { Атипова ампутація переднього } \\
\text { відділу стопи }\end{array}$ & 6 & 4,7 & 81,1 \\
\hline $\begin{array}{l}\text { Екзартикуляція фаланг пальців } \\
\text { стопи }\end{array}$ & 129 & 100,0 & \\
\hline Разом ... & & & \\
\hline
\end{tabular}

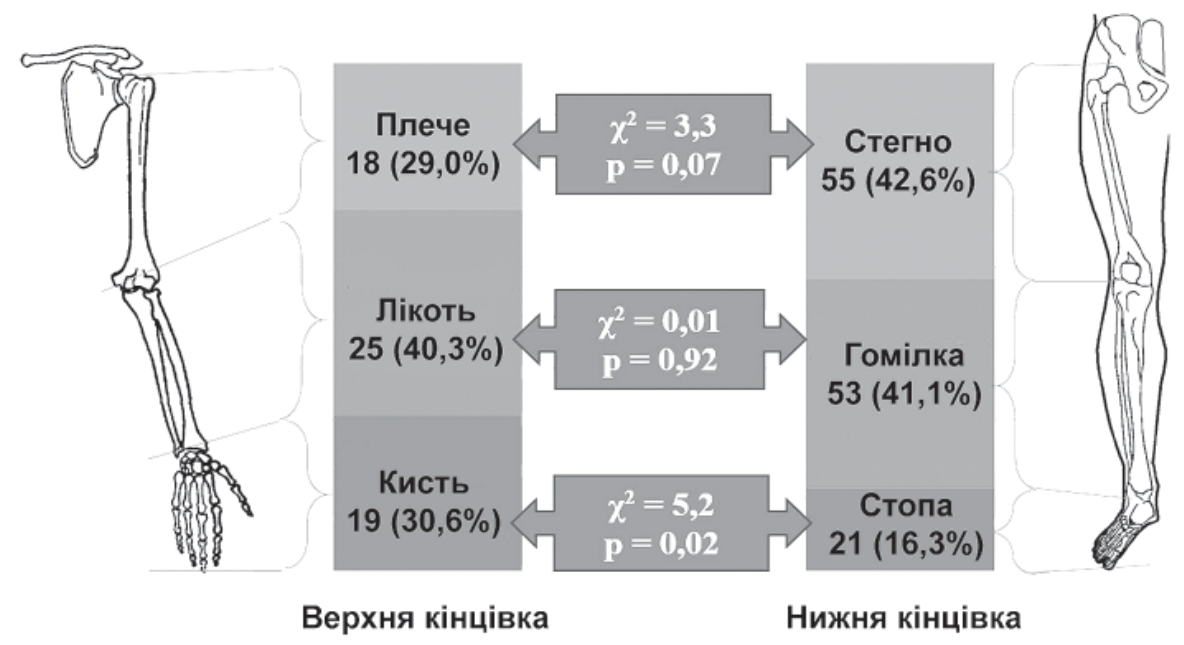

Структура ампутації кінцівок залежно від сегмента верхньої та нижньої кінцівки.

ки. Ампутація сегмента кінцівки виконана у 105 (81,4\%) постраждалих, екзартикуляція на рівні суглобів - у 24 (18,6\%). На проксимальному сегменті оперовані 55 (42,6\%) постраждалих, на гомілці - 53 (41,1\%), на дистальному сегменті - 21 (16,3\%). Частіше виконували ампутацію на середньому та проксимальному сегментах нижньої кінцівки $\left(\chi^{2}>50,0\right.$, $\mathrm{p}<0,001)$, що пов'язане $з$ більш масивними необоротними пошкодженнями ударною хвилею дистального та середнього сегментів нижньої кінцівки при мінно-вибухових пораненнях.

Екзартикуляцію достовірно частіше проводили на верхній кін- цівці $\left(\chi^{2}=5,4 ; p=0,02\right)$, ніж на нижній. Частота операцій залежно від сегмента ампутованої верхньої та нижньої кінцівок наведена на рисунку. Частота ампутації середнього сегмента (гомілка, передпліччя) обох кінцівок суттево не різнилася ( $\mathrm{p}=$ 0,92); дистального сегмента (пальці, стопа, надп'ятково-гомілковий суглоб) - була достовірно меншою $\left(\chi^{2}=5,2 ; \mathrm{p}=0,02\right)$, ніж відповідного сегмента верхньої кінцівки (пальці, кисть, променево-зап'ястковий суглоб). Частота ампутації проксимального сегмента нижньої кінцівки (стегно, кульшовий суглоб) була достовірно більшою $\left(\chi^{2}=3,3, \mathrm{p}=0,7\right)$, ніж відповідного сегмента верхньої 
кінцівки (плече, плечовий суглоб). Зазначені особливості рівня ампутації верхньої та нижньої кінцівок слід мати на увазі при визначенні потреби у протезуванні кінцівок. Так, для нижньої кінцівки більш часто виникає необхідність протезування проксимального або середнього сегмента, для верхньої кінцівки - потреба у протезуванні усіх трьох сегментів майже однакова.

\section{ВИСНОВКИ}

1. В структурі бойової хірургічної травми переважала (p < 0,001) ампутація нижньої кінцівки (67,5\%), ніж верхньої $(32,5 \%)$.

2. Частота ампутації різних сегментів верхньої кінцівки суттево не різнилася $(\mathrm{p}=0,35)$ : плечового сегмента - 29,0\%, ліктьового - 40,3\%, кисті- 30,6\%.

3. Частота ампутації стегнового (42,6\%) та гомілкового (41,1\%) сег- ментів нижньої кінцівки достовірно більша ( $<$ < 0,001) ніж сегмента стопи $(16,3 \%)$.

4. Частота ампутації верхньої та нижньої кінцівок достовірно різнилася $(p=0,02)$ лише на рівні сегментів кисті (30,6\%) та стопи (16,3\%).

5. Клініко-статистичні дані щодо структури ампутації кінцівок у постраждалих слід мати на увазі при визначенні потреби у протезуванні відповідних сегментів кінцівок.

\section{REFERENCES}

1. Bodalal Z, Mansor S. Gunshot injuries in Benghazi-Libya in 2011: the Libyan conflict and beyond. Surgeon. 2013;11(5):258-63.

2. Rathore FA, Ayaz SB, Mansoor SN, Qureshi AR, Fahim M. Demographics of lower limb amputations in the Pakistan military: a single center, three-year prospective survey. Cureus. 2016;11(8):566.

3. Ebrahimzadeh MH, Moradi A, Khorasani MR, Hallaj-Moghaddam M, Kachooei AR. Long-term clinical outcomes of war-related bilateral lower extremities amputations. Injury. 2015;46(2):275-81.

4. Tsema IE, Bespalenko A. Analysis of limb amputations during armed conflict at the East of Ukraine. Norwegian Journal of Development of the International Science. 2016;(1):79-80.

5. Bertani A, Mathieu L, Dahan JL, et al. War-related extremity injuries in children: 89 cases managed in a combat support hospital in Afghanistan. Orthop Traumatol Surg Res. 2015;101(3):365-8.

6. Akkucuk S, Aydogan A, Yetim I, et al. Surgical outcomes of a civil war in a neighbouring country. J R Army Med Corps. 2016;162(4):25660 .

7. Khmehl VV, Mayetniy EM, Levshov YA. The treatment of injured persons with complicated penetrating thoracic woundings on tertiary level of the medical care delivery. Klinichna khirurhiia. 2016;(1):479. [In Ukrainian].

8. Rozin YA, Ivanenko AA. Early specialized surgical care for gunshot wounds of major vessels in Donbas. Angiol Sosud Khir. 2016;22(2):156-60. [In Russian].

9. Schoenfeld AJ, Dunn JC, Bader JO, Belmont PJ Jr. The nature and extent of war injuries sustained by combat specialty personnel killed and wounded in Afghanistan and Iraq, 2003-2011. J Trauma Acute Care Surg. 2013;75(2):287-91.

10. Holt E. Health care collapsing amid fighting in east Ukraine. Lancet. 2015;7(385):494.

11. Jacobs $\mathrm{N}$, Rourke K, Rutherford J, et al. Lower limb injuries caused by improvised explosive devices: proposed "Bastion classification» and prospective validation. Injury. 2014;45(9):1422-8.

12. Schwartz D, Glassberg E, Nadler R, et al. Injury patterns of soldiers in the second Lebanon war. J Trauma Acute Care Surg. 2014;76(1):160-6. 